\title{
Trace Elements in Soils of a Typical Industrial District in Ningxia, Northwest China: Pollution, Source, and Risk Evaluation
}

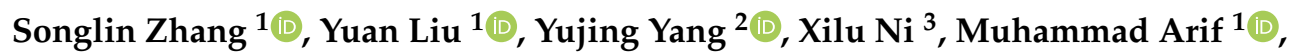 \\ Wokadala Charles ${ }^{1}$ and Changxiao $\mathrm{Li}^{1}{ }^{1 \text { ** }}$ \\ 1 Key Laboratory of Eco-environments in Three Gorges Reservoir Region (Ministry of Education), \\ Chongqing Key Laboratory of Plant Ecology and Resources Research in Three Gorges Reservoir Region, \\ School of Life Sciences, Southwest University, Chongqing 400715, China; slzhang@email.swu.edu.cn (S.Z.); \\ liuyuan20100901@163.com (Y.L.); muhammadarif@swu.edu.cn (M.A.); \\ walkerdarlercharles@yahoo.com (W.C.) \\ 2 Faculty of Resources and Environmental Sciences, Hubei University, Wuhan 430062, China; \\ yyjzh158@hubu.edu.cn \\ 3 Breeding Base for State Key Laboratory of Land Degradation and Ecological Restoration of North-western China, \\ Key Lab for Restoration and Reconstruction of Degraded Ecosystem in North-western China \\ (Ministry of Education), Ningxia University, Yinchuan 750000, China; nixilu110@163.com \\ * Correspondence: lichangx@swu.edu.cn; Tel.: +86-23-6825-2365
}

Received: 11 February 2020; Accepted: 28 February 2020; Published: 2 March 2020

\begin{abstract}
Intense industrial activities could result in massive accumulations of trace elements in the soil and risk the terrestrial ecosystems and human health. A total of 119 topsoil samples from a typical industrial area, Huinong District, Ningxia, Northwest China, were collected, and the contents of six trace elements ( $\mathrm{As}, \mathrm{Cd}, \mathrm{Cr}, \mathrm{Cu}, \mathrm{Pb}$, and $\mathrm{Zn}$ ) were determined. The results indicated that the mean concentrations of $\mathrm{Cr}, \mathrm{Cu}, \mathrm{Pb}$, and $\mathrm{Zn}$ were lower than the national standard values of class II, while As and $\mathrm{Cd}$ were 2.77 and 3.92 times the corresponding threshold values. Multivariate analyses revealed six metals can be categorized into three principal components (PC). PC1 was As, Cd, and $\mathrm{Pb}$, which originated from anthropogenic inputs. $\mathrm{PC} 2$ consisted of $\mathrm{Cr}$ and $\mathrm{Cu}$, which originated from the natural geological background. PC3 only included Zn and was mainly due to agricultural impacts. The spatial distribution of six metals greatly varied from local anthropic inputs. For As and $\mathrm{Cd}$, the most heavily polluted area was located in the north and southwest parts of the study area, whereas most $\mathrm{Zn}$ was enriched in the southern part, which was mainly agricultural land. The topsoil in this area displayed a moderate environmental risk with the metal pollution order of $\mathrm{Cd}>\mathrm{As}>\mathrm{Zn} \approx \mathrm{Cr} \approx \mathrm{Pb} \approx \mathrm{Cu}$. Moreover, the contents of trace elements in the industrial land and water were relatively higher than those in other land-use types, indicating a considerable risk of metal migration and accumulation to rivers and the groundwater. It is suggested that effective remediation measures for $\mathrm{Cd}$ and $\mathrm{As}$, in particular, should be properly employed for the sustainable development of the soil and groundwater, while reducing the risk of elements to the local residents in Huinong District.
\end{abstract}

Keywords: trace element; soil pollution; industrial area; spatial distribution; potential ecological risk; multivariate analysis; source

\section{Introduction}

Soil is not only a carrier for plant growth and the final "sink" of numerous hazardous substances but also a transitional phase for the transmission and migration of pollutants to the atmosphere, 
organisms, and groundwater [1-4]. Among those pollutants, soil pollution with trace metals and metalloids has attracted global attention and become a concerned environmental issue in the past few decades. Due to the obvious non-degradability and latency of soil trace metal(loid)s, it is difficult to detect and has a long incubation period before the danger and toxicity of excessive metals in the soil can be realized. Once the soil is contaminated, the metal elements can be probably transferred into other geographic environments through the soil, and would eventually accumulate into human bodies through the food chain, drinking water, and dust inhalation [4-6]. Moreover, the long-term accumulation of trace elements in the soil poses a great threat to human health and the sustainable development of the ecological environment [7].

The level of metal is a crucial indicator to evaluate the quality and status of the local environment. Metals in the soil do not migrate or break down easily and may accumulate partly from natural factors, such as geological background formation and weathering [8]. However, in most areas, anthropogenic activities, especially various industrial activities, such as smelting, mining, coal-fired power generation, and fossil fuel combustion, have profoundly impacted the enrichment of abundant metal(loid)s in soil far beyond the natural diagenesis $[7,9,10]$. Intensive activities of industrial production import trace elements into the soil, directly or indirectly, through exhaust gas, wastewater, or solid waste. Moreover, most industrial parks are located on the edge of, or close to, rivers for better access to water resources, which may lead to severe contamination to the water body through surface runoff or groundwater circulation [11,12]. The enrichment of metal elements in urban soil can also be derived from the extensive application of fertilizers and pesticides, as well as transportation and automobile exhaust emissions $[13,14]$. Moreover, the pattern of metal(loid) pollution usually highly relates to human activities and land-use types and may thus exert different effects on public health $[15,16]$. Therefore, identifying the sources and spatial distribution of soil trace metal(loid)s, particularly in industrialized areas, is of great significance for effective management measures to control pollution levels and improve soil quality.

Multivariate analytical methods, including correlation analysis, principal component analysis (PCA), and cluster analysis (CA), are useful tools to disentangle potential sources of trace metal(loid)s in the soil or sediment $[17,18]$. The geostatistical analysis is based on geographical information science (GIS), containing a variety of spatial interpolation approaches. Among these, kriging interpolation, a stochastic regional variable-based model, is most widely used in the studies of trace element pollution due to the wide applicability and unbiased estimator $[19,20]$. Kriging also provides relevant information on the spatial structure and prediction of metals. Multivariate and geostatistical analyses are often integrated to comprehensively disentangle the pollution characteristics and to discriminate the potential inputs of metal(loid)s [20-22].

In recent years, most studies on trace element pollution are mainly concentrated in Central and Southeast China, while less attention is paid to the northwest inland region, with fragile habitats and a harsh but vulnerable eco-environment [23-25]. The full implementation of the Western Development Policy in China has successfully shifted numerous industries from the east to the west. However, the western region of China is seriously limited by vegetation, rainfall, climate, and other factors. The soil in many areas is highly salinized and extremely susceptible to metal(loid) pollution caused by industrial activities [26]. Hence, research on the assessment of trace-element pollution in industrial parks of Western China is urgently required. On the basis of the assessment, adequate remediation techniques, such as phytoremediation, can be employed to strengthen the sustainable development of regional natural resources.

Shizuishan is a traditional industrial city located in the northwest inland region of Ningxia Autonomous Region, China. The dominant industries of Shizuishan consist of mining, smelting, fuel production, coal combustion, chemical, and power transmission, the majority of which are located in Huinong District and are known to release abundant contaminants into the soil and water [27]. As a result of increased industrial activities, a strong trend of metal(loid) accumulation in the soil and groundwater has been revealed in this area. For example, Wang et al. [26] found that the 
industrial zone caused an obvious metal enrichment in agricultural soils and irrigation water of Ningxia. Industrial contamination was also found to be the main reason for high risk in groundwater in the Yinchuan Region, Northwest China [28]. However, the spatial features and origins of trace element pollution in Huinong District, caused largely by various industrial inputs, are still unclear. Therefore, this study attempts to investigate the pollution characteristics, potential sources, and environmental risk assessment of six soil trace elements, namely $\mathrm{As}, \mathrm{Cd}, \mathrm{Cr}, \mathrm{Cu}, \mathrm{Pb}$, and $\mathrm{Zn}$, in different land-use types in the typical industrial region, Huinong District. This study will provide a reference for the systematic evaluation and remediation of soil contamination and for sustainable management of the land in such a unique habitat of the northwest industrial park, China.

\section{Materials and Methods}

\subsection{Study Area}

The study area is located in Huinong District, Shizuishan City, Ningxia Hui Autonomous Region, which is a typical industrial gathering place in Northwest China and reaches a total area of $1254 \mathrm{~km}^{2}$ $\left(106^{\circ} 28^{\prime}-106^{\circ} 51^{\prime} \mathrm{E}, 38^{\circ} 57^{\prime}-39^{\circ} 5^{\prime} \mathrm{N}\right)$ (Figure 1). Huinong District is bordered by the Yellow River in the east and Helan Mountain in the west, with rich coal reserves and convenient transportation. The area has a temperate windy and dry climate, with a mean annual rainfall of $180 \mathrm{~mm}$ and annual evaporation of $1700-2500 \mathrm{~mm}$ [27]. The dominated landscape is desert grassland. The soil is mainly gray desert soil, and the soil texture is sandy or alkaline [29]. Several large industrial parks are distributed within the region, including Hebin Industrial Park, Hongguozi Industrial Park, and the Agricultural Products Processing Industrial Park. Due to the massive disruption caused by industrial activities, the eco-environment in this area has been increasingly damaged, and the vegetation coverage has become lower and fragmented. Restricted by rainfall, climate, vegetation, and other factors, Huinong District is relatively vulnerable to trace-element pollution and belongs to the "highly polluted area of the Ning-Meng junction area", under state key monitoring [24].

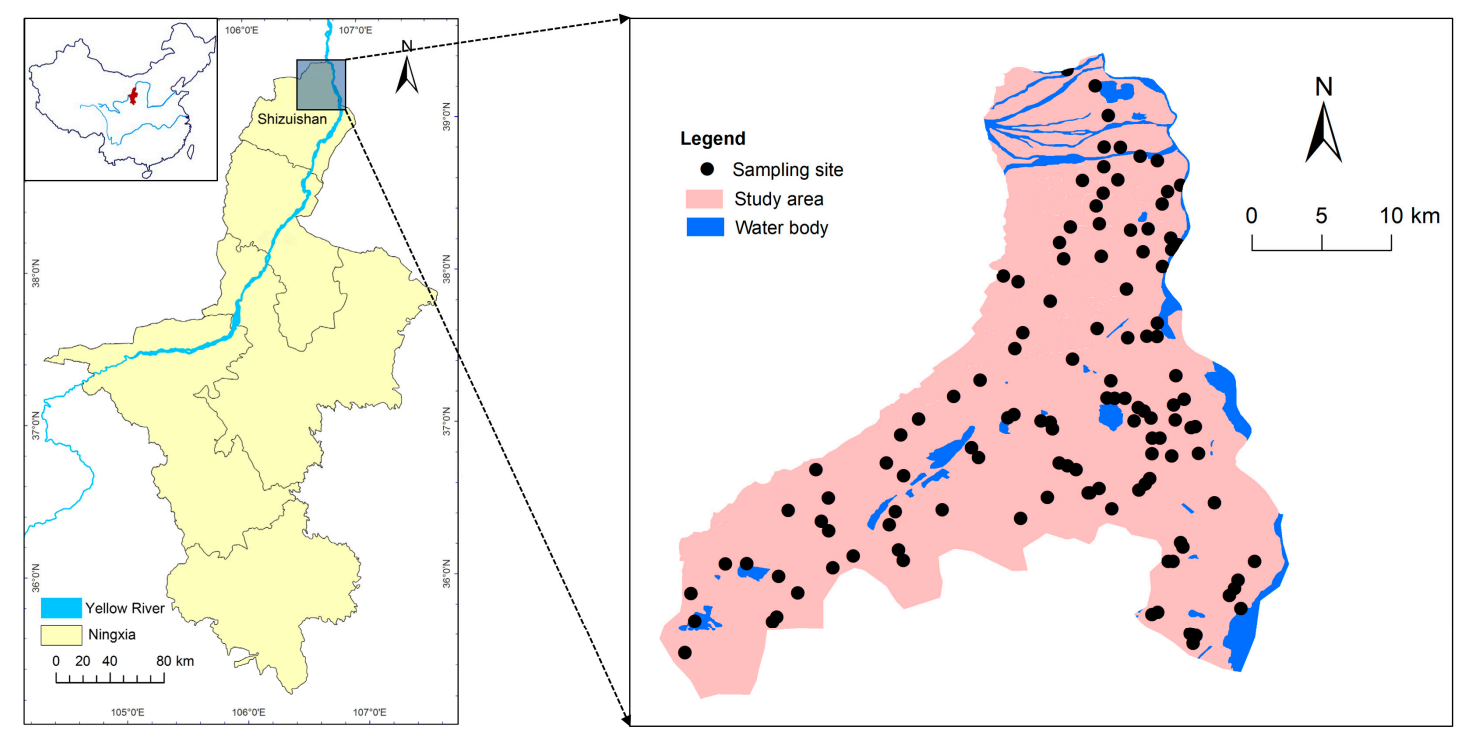

Figure 1. Locations of sampling map in Huinong District (right), Northwest China; red area on the inset map (left) is Ningxia Hui Autonomous Region.

\subsection{Soil Sampling and Analysis}

Combined with the remote sensing and satellite map and geomorphic factors, a total of 119 samples were collected from Huinong District in July 2015, classified into 6 land-use types, namely industrial land (IL), unutilized land (UL), water (W), agricultural land (AL), forest land (FL), and residential land (RL). The main crops in the AL were wheat (Triticum aestivum), maize (Zea mays), 
soybean (Glycine max), and sunflower (Helianthus annuus). Within a single sampling site, the surface soil $(0-20 \mathrm{~cm})$ at the central and four corner points was collected, using a stainless-steel spade, and thoroughly blended. Then, $500 \mathrm{~g}$ of the mixed soil sample was generated by the quartation method. Stones, plant debris, and other impurities were discarded. The composited soil was air-dried, sieved through $2 \mathrm{~mm}$, and ground to pass through $0.149 \mathrm{~mm}$ (100-mesh), for the element concentration analysis [30]. The longitude and latitude of each sampling site were recorded, using a global positioning system (GPS) device.

In total, $50 \mathrm{mg}$ of the soil sample was digested with a mixture of $\mathrm{HNO}_{3} / \mathrm{H}_{2} \mathrm{O}_{2} / \mathrm{HF}(7: 2: 1, \mathrm{v} / \mathrm{v} / \mathrm{v})$, in a microwave digestion system (MWS-4, Berghof, Germany), at $140{ }^{\circ} \mathrm{C}$. The solution was heated, using a crucible to remove the remaining hydrofluoric acid, and then it was adjusted to $50 \mathrm{~mL}$ with $0.1 \% \mathrm{HNO}_{3}(\mathrm{v} / \mathrm{v})$ and filtered. The concentration of $\mathrm{As}, \mathrm{Cd}, \mathrm{Cr}, \mathrm{Cu}, \mathrm{Pb}$, and $\mathrm{Zn}$ was determined in Inductively Coupled Plasma-Optical Emission Spectrometry (ICP-OES, Thermo Fisher, USA). All the analyses were performed in triplicate.

\subsection{Assessment of Soil Pollution}

To evaluate the pollution level of six trace elements and the ecological risk in the soil of Huinong District, the Nemerow synthetic pollution index (NPI) [31] and potential ecological risk index (PERI) were introduced in this study.

NPI is a comprehensive method widely used for the degree of soil trace-element contamination. It is calculated by Equation (1).

$$
\mathrm{NPI}=\sqrt{\frac{\left(\frac{C_{i}}{S_{i}}\right)_{\max }^{2}+\left(\frac{C_{i}}{S_{i}}\right)_{\mathrm{ave}}^{2}}{2}} .
$$

where $C_{i}$ is the concentration of the metal, $i$, in the soil sample, and $S_{i}$ is the Class II of Chinese Soil Environmental Quality Standards (GBl5618-1995, $\mathrm{pH}>7.5$ ), given that the soil in the study area is mainly alkaline. The threshold values for $\mathrm{As}, \mathrm{Cd}, \mathrm{Cr}, \mathrm{Cu}, \mathrm{Pb}$, and $\mathrm{Zn}$ are 25, 0.6, 250, 100, 350, and $300 \mathrm{mg} \cdot \mathrm{kg}^{-1}$, respectively [32]. The subscripts max and ave refer to the maximum and average values of $C_{i} / S_{i}$ among the tested metals for each soil sample. The grade standard of NPI was interpreted according to [27].

PERI was proposed by Hakanson [33] and can reflect the potential effect of various trace elements on the ecological environment. It is computed by Equation (2):

$$
\text { PERI }=\sum_{i=1}^{n} E_{r}^{i}=\sum_{i=1}^{n} T_{r}^{i} \times C_{f}^{i}=\sum_{i=1}^{n} \frac{T_{r}^{i} \times C_{o}^{i}}{S_{n}^{i}}
$$

where $E_{r}^{i}$ is the ecological hazard index for the metal, $I ; T_{r}^{i}$ is the toxic-response coefficient; and $C_{o}^{i}$ and $S_{n}^{i}$ refer to the determined concentration and the standard value for the metal, $i$, respectively. According to Hakanson [33], the toxic-response coefficients for $\mathrm{As}, \mathrm{Cd}, \mathrm{Cr}, \mathrm{Cu}, \mathrm{Pb}$, and $\mathrm{Zn}$ are 10, 30, 2, 5,5 , and 1 , respectively.

\subsection{Statistical Analysis and Spatial Distribution}

Multivariate analysis methods, namely Pearson correlation analysis, principal component analysis (PCA), and cluster analysis (CA), were performed to identify the potential source of trace elements in Huinong District. The ward-algorithmic method was applied in CA [34]. The concentration of six metals under different land-use types was compared by one-way analysis of variance (ANOVA), followed by Duncan's multiple range test at the 0.05 level. All the procedures were performed in SPSS 22.0 statistical package (IBM, USA). Data normality was checked before processing and log or Box-Cox transformed when required. 
The semivariogram model $(\gamma(h))$ in the geostatistical analysis was employed for spatial interpolation analysis of metals. It is calculated as follows [35]:

$$
\gamma(h)=\frac{1}{2 N(h)} \sum_{i=1}^{N(h)}\left[z\left(x_{i}\right)-z\left(x_{i}+h\right)\right]^{2}
$$

where $\mathrm{N}(h)$ is the pair number of samples with the lag distance of $h$, and $z\left(x_{i}\right)$ is the metal concentration at the location of $\mathrm{x}_{i}$. In this study, the best fit model and parameters for kriging interpolation were determined based on the semivariogram formula, and ordinary kriging was then applied to map the spatial pattern of metals in ArcGIS 9.3 (ESRI, USA).

\section{Results and Discussion}

\subsection{Concentrations of Trace Elements}

The descriptive statistical results for six trace elements are presented in Table 1 and Supplementary Figure S1. The concentrations of six elements greatly vary within the study area. $\mathrm{Zn}$ was found in the highest concentrations, followed by $\mathrm{Pb}$ and $\mathrm{As}$. The measured values of $\mathrm{Cd}$ were relatively low. The average concentrations of $\mathrm{As}, \mathrm{Cd}, \mathrm{Cr}, \mathrm{Cu}, \mathrm{Pb}$, and $\mathrm{Zn}$ were 69.24, 2.35, 71.41, 15.93, 68.36, and $220.48 \mathrm{mg} \mathrm{kg}^{-1}$, respectively (Table 1). Five of the six metals, $\mathrm{As}, \mathrm{Cd}, \mathrm{Cr}, \mathrm{Pb}$, and $\mathrm{Zn}$, were higher than the background values of Ningxia, indicating that human activities influenced the enrichment of soil trace elements. As compared with the class II threshold of Chinese Soil Environmental Quality Standards, only As and Cd means were higher than the threshold value, which was 2.77- and 3.92-fold higher than the corresponding threshold value, respectively. The exceeding standard rate of As and Cd was also relatively high, occupying $74.8 \%$ and $79.0 \%$ of the whole sampling sites, respectively. This indicates that As and Cd might be enriched in Huinong District and require more attention in the future.

Table 1. Descriptive statistics of trace element concentrations in soil samples $\left(\mathrm{mg} \mathrm{kg}^{-1}\right)$.

\begin{tabular}{ccccccc}
\hline Item & As & $\mathbf{C d}$ & $\mathbf{C r}$ & $\mathbf{C u}$ & $\mathbf{P b}$ & $\mathbf{Z n}$ \\
\hline Mean & 69.24 & 2.35 & 71.41 & 15.93 & 68.36 & 220.48 \\
Minimum & 1.08 & 0.04 & 43.60 & 10.00 & 9.30 & 128.90 \\
Maximum & 176.65 & 8.41 & 146.20 & 35.00 & 194.80 & 360.60 \\
Median & 67.55 & 2.20 & 69.90 & 15.20 & 59.20 & 219.80 \\
S.D. & 46.63 & 1.76 & 15.77 & 4.41 & 41.00 & 42.45 \\
C.V. (\%) & 67.34 & 74.85 & 22.08 & 27.68 & 59.98 & 19.25 \\
Skewness & 0.24 & 0.94 & 1.98 & 1.75 & 0.78 & 0.13 \\
Kurtosis $^{\text {a }}$ & -0.97 & 1.04 & 6.77 & 4.68 & 0.03 & 0.22 \\
Background value in Ningxia $^{1}$ & 11.90 & 0.11 & 60.00 & 22.10 & 20.60 & 58.80 \\
Threshold value $^{2}$ & 25 & 0.6 & 250 & 100 & 350 & 300 \\
\hline
\end{tabular}

${ }^{1}$ China National Environmental Monitoring Station. Background Values of Soil Elements in China. China Environmental Science Press, Beijing. 1990; p 339-386. ${ }^{2}$ Class II of Chinese Soil Environmental Quality Standards (GB15618-1995, $\mathrm{pH}>7.5)$.

\subsection{Identification of Trace-Element Sources}

The relationships between six trace elements were examined by Pearson correlation analysis (Table 2). As shown in Table 2, soil As, $\mathrm{Cd}, \mathrm{Pb}, \mathrm{Cu}$, and $\mathrm{Cr}$ were highly correlated with each other $\left(r=0.315^{* *}-0.938^{* *}\right)$, suggesting that sources of these metals might be similar. Zn was correlated with none of the other metals, which might indicate a different influential factor for this element. Relationships between the six elements were rather complicated, and the results of correlation analysis should, therefore, be combined with other multivariate methods, to better clarify the source of soil trace elements. 
Table 2. Pearson correlation coefficients for trace elements in Huinong District.

\begin{tabular}{ccccccc}
\hline & As & Cd & Cr & $\mathbf{C u}$ & Pb & Zn \\
\hline $\mathrm{As}$ & 1.000 & - & - & - & - & - \\
$\mathrm{Cd}$ & $0.938^{* *}$ & 1.000 & - & - & - & - \\
$\mathrm{Cr}$ & $0.316^{* *}$ & $0.315^{* *}$ & 1.000 & - & - & - \\
$\mathrm{Cu}$ & $0.332^{* *}$ & $0.343^{* *}$ & $0.471^{* *}$ & 1.000 & - & - \\
$\mathrm{Pb}$ & $0.597^{* *}$ & $0.613^{* *}$ & $0.530^{* *}$ & $0.513^{* *}$ & 1.000 & - \\
$\mathrm{Zn}$ & -0.063 & -0.084 & -0.006 & 0.139 & -0.032 & 1.000 \\
\hline \multicolumn{7}{c}{ Note: ${ }^{*} p<0.05,{ }^{* *} p<0.01}$.
\end{tabular}

To better disentangle the origins and relationships among trace elements, PCA was performed in the current study. The PCA results of factor loadings are listed in Table 3. According to the eigenvalues higher than one, three principal components were extracted from the data matrix that accounted for $86.4 \%$ of the total variation of soil metals. The first component (PC1) explained $41.35 \%$ of the total variance and loaded heavily on $\mathrm{As}, \mathrm{Cd}$, and $\mathrm{Pb}$. The second component (PC2), dominated by $\mathrm{Cr}$ and $\mathrm{Cu}$, accounted for $27.45 \%$ of the total variance. The third component (PC3) was mainly loaded by $\mathrm{Zn}$ and explained $17.60 \%$ of the total variance. The spatial distance of the three principal components is also shown in Figure 2a, where the correlations among metals are exhibited.

Table 3. Rotated component matrix for six trace elements in Huinong District.

\begin{tabular}{cccc}
\hline \multirow{2}{*}{ Element } & \multicolumn{3}{c}{ Component } \\
\cline { 2 - 4 } & PC1 & PC2 & PC3 \\
\hline $\mathrm{As}$ & $\mathbf{0 . 9 6 3}$ & 0.157 & 0.009 \\
$\mathrm{Cd}$ & $\mathbf{0 . 9 6 9}$ & 0.153 & 0.010 \\
$\mathrm{Cr}$ & 0.133 & $\mathbf{0 . 9 0 3}$ & -0.068 \\
$\mathrm{Cu}$ & 0.308 & $\mathbf{0 . 7 4 6}$ & 0.295 \\
$\mathrm{~Pb}$ & $\mathbf{0 . 7 0 8}$ & 0.470 & -0.058 \\
$\mathrm{Zn}$ & -0.031 & 0.066 & $\mathbf{0 . 9 8 0}$ \\
Eigenvalue & 2.481 & 1.647 & 1.056 \\
\% of variance & 41.349 & 27.447 & 17.598 \\
\% of cumulative & 41.349 & 68.796 & 86.395 \\
\hline
\end{tabular}

Extraction method: principal component analysis; rotation method: varimax with Kaiser normalization. Rotation converged in four iterations.

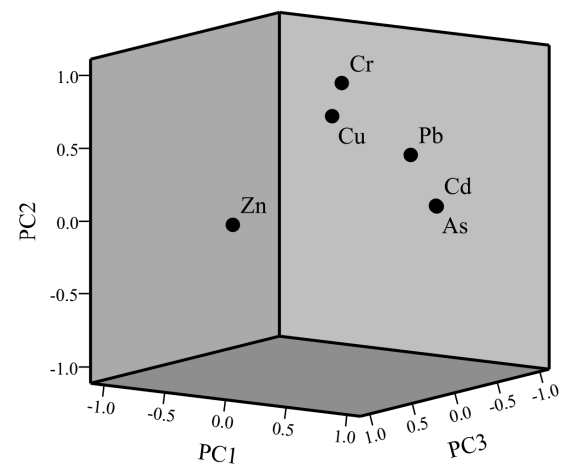

(a)

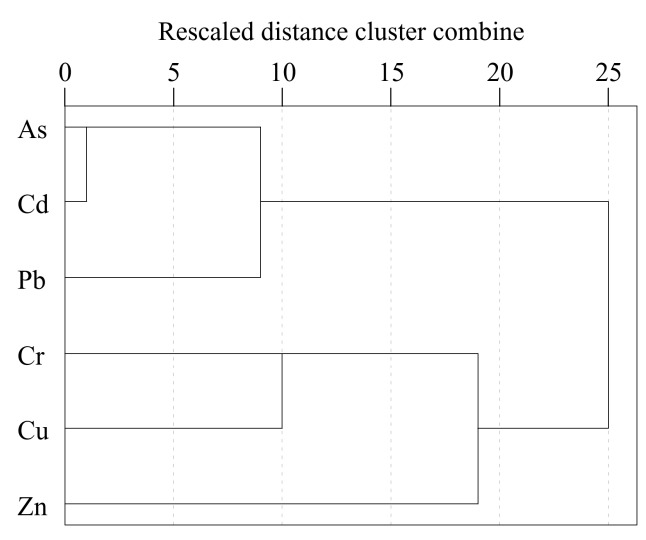

(b)

Figure 2. Loading plot of principal component analysis (a) and dendrogram results from Ward method of hierarchical cluster analysis (b) for six trace elements in Huinong District.

CA is usually coupled with PCA to discriminate the source similarities and confirm the results of the grouping component $[9,21]$. In this study, CA was performed for the six trace elements in the soil 
samples, and the results are shown in Figure $2 \mathrm{~b}$. Six elements were categorized into three main clusters: (1) As, $\mathrm{Cd}$, and $\mathrm{Pb}$; (2) $\mathrm{Cr}$ and $\mathrm{Cu}$; (3) $\mathrm{Zn}$. The result was in line with the PCA results, and the three clusters were feasible to represent various sources of the trace elements in the soil of Huinong District.

The results of PCA and CA indicated that three main potential sources of the elements were clearly presented. The first source consisted of $\mathrm{As}, \mathrm{Cd}$, and $\mathrm{Pb}$, which were also closely correlated with each other $(p<0.01$, Table 2$)$. Studies revealed that coal combustion, metal smelting, and cement manufacturing significantly led to the enrichment of $\mathrm{Cd}$ and As in the soil $[9,36]$. Meanwhile, $\mathrm{Pb}$ is typically associated with transportation and exhaust emissions [37]. Therefore, anthropogenic inputs from industrial practices and vehicular exhaust were primarily responsible for the first source.

The second source was mainly composed of $\mathrm{Cr}$ and $\mathrm{Cu}$. Compared with those in PC1, the contents of $\mathrm{Cr}$ and $\mathrm{Cu}$ were substantially lower, and their spatial pattern was also similar (Figure 3). Generally speaking, the content of these two elements in the soil is greatly influenced by the parent material. For example, Zhao et al. [38] found that Cr mainly originated from the parent soil material in an industrial district of Northern China. Rodríguez Martín et al. [39] found that the effect of animal manure, limestone, and organic fertilizer on $\mathrm{Cr}$ and $\mathrm{Cu}$ content in soil was less than that of soil background itself. In the present study, $\mathrm{Cr}$ and $\mathrm{Cu}$ contents were in close proximity to the background values in Ningxia and were 0.29 - and 0.16 -fold of the threshold value, respectively (Table 1 ). This suggests that the two metals presumably derive from soil parent materials and are less impacted by human activities in the study area. The loading of $\mathrm{Pb}$ in $\mathrm{PC} 2$ was 0.47 , implying that $\mathrm{Pb}$ originated from mixed sources of human activity and natural geologic background.

The third source was dominated by Zn. There were many crops, such as wheat and maize, and some vineyards planted in the study area, which may be an important source for the input of soil $\mathrm{Zn}$. It is reported that soil $\mathrm{Zn}$ enrichment is highly associated with agricultural practices [40]. Zn-containing compounds are commonly used in pesticides and water-soluble fertilizers, and livestock manures also contain high levels of $\mathrm{Zn}$ because it is often fed as a trace supplement [37]. Hence, the third source could be classified as agricultural production.

\subsection{Spatial Distribution of Trace Elements}

The spatial pattern of hazardous substances is an essential prerequisite for identifying the hot spot of the contaminated area and monitoring the regional eco-environment $[13,41,42]$. In the current study, the geostatistics method was performed to obtain the best-fitted semivariogram (Supplementary Table S1), and the visualization of ordinary kriging interpolation results is shown in Figure 3, based on the fitted semivariogram models.

As shown in Figure 3, the spatial distribution of As and Cd exhibited a comparative similarity, and both were found in high concentrations in the north and southwest parts of the study area. Coincidentally, there are several large energy-consuming enterprises in these regions, such as coal, electricity, cement, building materials and hardware, and other industrial activities, which lead to serious pollution of $\mathrm{Cd}$ and $\mathrm{As}$ in the research area. This supported the view that As and $\mathrm{Cd}$ were mainly derived from the industrial and anthropic inputs nearby. Spatial variability in the concentrations of $\mathrm{Cu}$ and $\mathrm{Cr}$ was generally low and smooth in Huinong District, implying that the natural factor controlled their distributions as an important role. Distribution of $\mathrm{Pb}$ was relatively continuous, the highest spot was found in the northwest of the region, which was comparable with that of As and Cd. Conversely, the spatial pattern of the $\mathrm{Zn}$ element was fairly distinct from that of the other metals. The area with high concentrations of $\mathrm{Zn}$ was mainly distributed in the south of the study area, with a relatively lower fluctuation throughout the area. Most of the south part in Huinong District was agricultural land (Figure 1), supporting the results of multivariate analysis that soil Zn mainly originated from the wide application of agricultural practices, such as the spread of chemical fertilizers and pesticides $[34,43]$. 


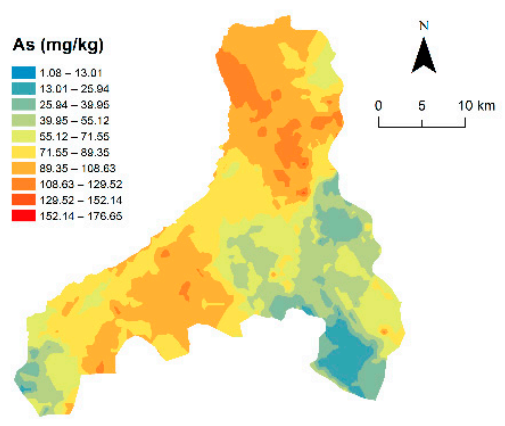

(a)

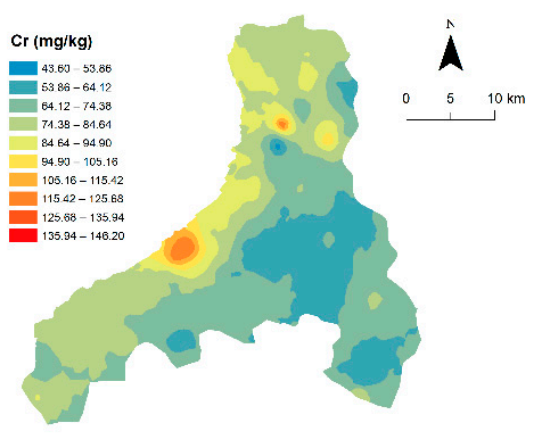

(c)

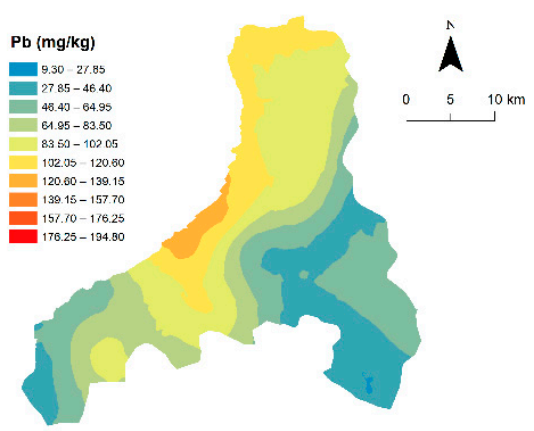

(e)

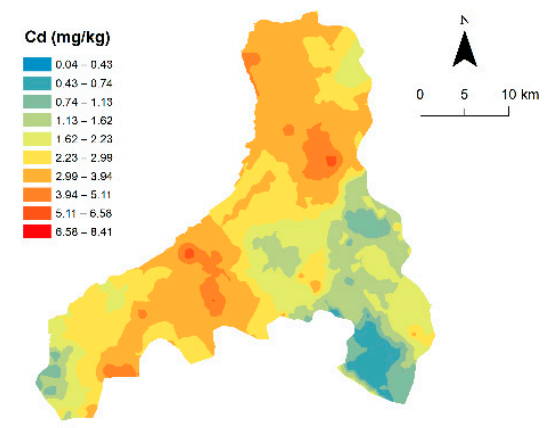

(b)

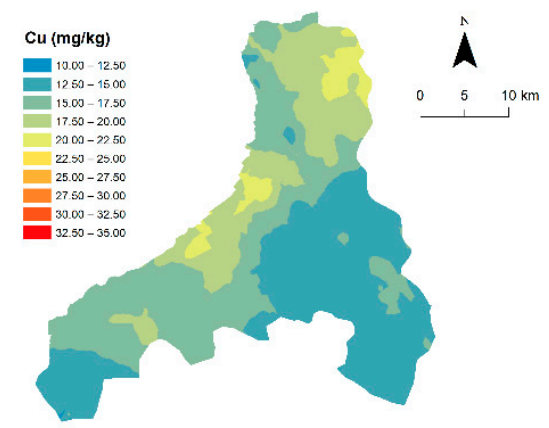

(d)

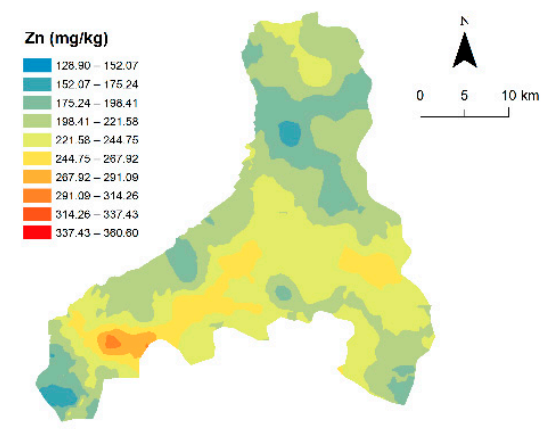

(f)

Figure 3. Spatial distribution of trace-element concentrations in the topsoil of Huinong District obtained by ordinary kriging.

\subsection{Environmental Risk Assessment of Trace-Element Pollution}

NPI and PERI assessment methods were employed to evaluate the environmental risk of trace-element pollution in the study area, and the results are presented in Table 4. For the metals, the outcomes of two assessment methods were consistent, with both showing the pollution order of $\mathrm{Cd}>\mathrm{As}>\mathrm{Zn} \approx \mathrm{Cr} \approx \mathrm{Pb} \approx \mathrm{Cu}$. Cd was found to be the most heavily polluted, and As was moderately polluted. The other four metals were practically unpolluted. The NPI values ranged from 0.33 to 10.23 , with a mean of 2.96 , displaying a moderate pollution level throughout the study area. The spatial pattern of NPI showed that the area with heavy pollution was mainly located in the north and southwest parts (Figure $4 \mathrm{a}$ ), which was in agreement with that of As and Cd and corresponded with the locations of industrial parks and metal processing plants in the study area. Results of the individual potential ecological risk showed that $\mathrm{Cd}$ was also found with the highest pollution risk, followed by As. The comprehensive PERI showed a moderate risk of the study area, with a mean of 176.18. Moreover, the spatial distribution of PERI was quite similar to that of NPI (Figure 4b). Therefore, industrial and anthropogenic activities were responsible for the high environmental risk of 
soil metal contamination, and actions should be promptly taken to reduce the threat of metal exposure and to ensure the quality and safety of crops and vegetables.

Table 4. Soil trace-element pollution and potential ecological risk assessment in Huinong District.

\begin{tabular}{|c|c|c|c|c|c|c|c|c|c|c|c|c|c|c|}
\hline Item & \multicolumn{6}{|c|}{$P_{i}^{a}$} & $N P I^{a}$ & \multicolumn{6}{|c|}{$E_{r}^{i^{b}}$} & PERI $^{b}$ \\
\hline Mean & 2.77 & 3.92 & 0.29 & 0.16 & 0.20 & 0.73 & 2.96 & 55.39 & 117.71 & 0.57 & 0.80 & 0.98 & 0.73 & 176.18 \\
\hline Maximum & 7.07 & 14.02 & 0.58 & 0.35 & 0.56 & 1.20 & 10.23 & 141.32 & 420.50 & 1.17 & 1.75 & 2.78 & 1.20 & 555.02 \\
\hline S.D. & 1.87 & 2.94 & 0.06 & 0.04 & 0.12 & 0.14 & 2.11 & 37.30 & 88.10 & 0.13 & 0.22 & 0.59 & 0.14 & 124.25 \\
\hline
\end{tabular}

$P_{i}$ is the single factor pollution index for the metal $i$ and calculated by the ratio of $C_{i} / S_{i} ;$ NPI is Nemerow synthetic pollution index; $E_{r}^{i}$ is the individual ecological risk index; and PERI is the total potential ecological risk index. N: no pollution (clean). L: low risk. M: moderate pollution or risk. C: considerable risk. H: high pollution. ${ }^{a} P_{i} \leq 1$ and $\mathrm{NPI} \leq 0.7$ indicate clean; $0.7<\mathrm{NPI} \leq 1$ is the warn limit range; $1<P_{i} \leq 2$ and $1<\mathrm{NPI} \leq 2$ mean low pollution; $2<\mathrm{Pi}$ $\leq 3$ and $2<\mathrm{NPI} \leq 3$ indicate moderate pollution; $P_{i}>3$ and NPI $>3$ indicate high pollution. ${ }^{\mathrm{b}} E_{r}^{i}<40$ and PERI $<$ 150 indicate low risk; $40 \leq E_{r}^{i}<80$ and $150 \leq$ PERI $<300$ indicate moderate risk; $80 \leq E_{r}^{i}<160$ and $300 \leq \mathrm{PERI}<600$ indicate considerable risk; $160 \leq E_{r}^{i}<320$ is high risk; and $E_{r}^{i} \geq 320$ and PERI $\geq 600$ indicate very high risk.

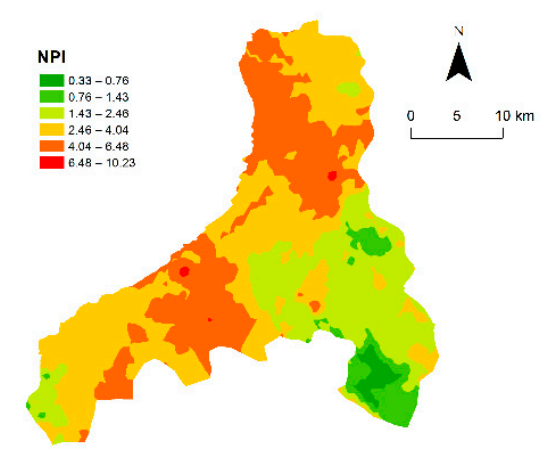

(a)

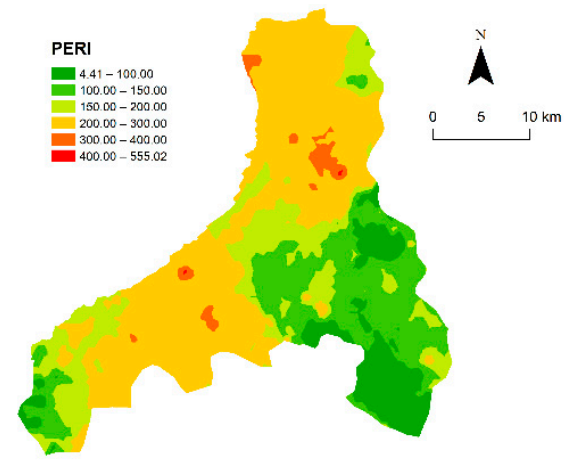

(b)

Figure 4. The evaluation map of trace element pollution in Huinong District: (a) Nemerow's pollution index, NPI; (b) potential ecological risk index, PERI.

\subsection{Effects of Land-Use Types on the Content of Trace Elements}

Land-use type is a significant factor that drastically affects trace-element content in the soil. In this study, the concentrations of six trace elements under different land-use types are presented in Figure 5. All the metals were significantly affected by land-use patterns, except Zn. Among all types of land use, As and $\mathrm{Cd}$ in the industrial land showed the highest concentrations of 105.03 and $3.63 \mathrm{mg} \mathrm{kg}^{-1}$, respectively (Figure 5). $\mathrm{Pb}$ content in the unutilized land was highest, reaching the mean of $97.86 \mathrm{mg} \mathrm{kg}^{-1}$, followed by that in the industrial land with the mean of $90.13 \mathrm{mg} \mathrm{kg}^{-1}$. Industrial activities such as coal combustion, mining waste, and electroplating are dominant sources of trace-element accumulation in the industrial zone [44,45]. The average contents of $\mathrm{Cd}, \mathrm{As}$, and $\mathrm{Pb}$ in the water body of the study area reached $3.03,96.85$, and $77.42 \mathrm{mg} \mathrm{kg}^{-1}$, implying that the water is likely to be another "sink" for trace-element inputs. Huinong District is adjacent to the Yellow River in the east. The trace elements in the water may eventually enter the Yellow River through surface runoff and groundwater flow, posing a serious threat to the middle and lower reaches of the Yellow River. Hence, the increase of trace-element content in water and sediment should be paid great attention. It is noteworthy that there were few samples collected in the water area of this study, and future research can be conducted on a more in-depth and comprehensive investigation into the status and migration characteristics of trace-element pollution in the regional water body. 

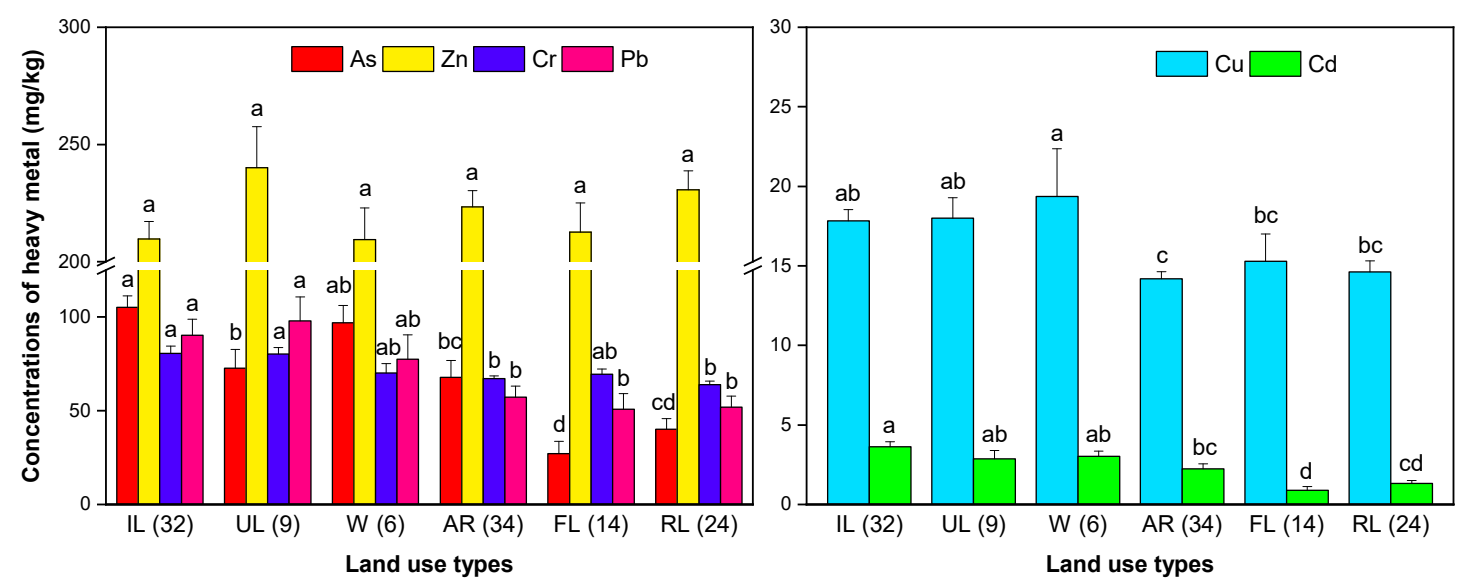

Figure 5. Trace-element concentrations in the topsoil of different land-use types in Huinong District. IL, UL, W, AR, FL, and RL refer to industrial land, unutilized land, water, agricultural land, forest land, and residential land, respectively. The number in parentheses indicates the sampling point of different land-use types. Different letters denote significant differences in element concentrations between land-use types $(p<0.05)$.

\section{Conclusions}

In this study, the spatial pattern, source identification, and environmental risk evaluation of six trace elements (As, Cd, Cr, Cu, $\mathrm{Pb}$, and $\mathrm{Zn}$ ) in the surface soil of Huinong District, an archetypal industrial district in Northwest China, were systematically investigated. The results revealed that the study area is generally moderately contaminated, as evidenced by the NPI and PERI analyses, with the main polluted areas being the north and southwest regions. Both methods showed the pollution risk order of $\mathrm{Cd}>\mathrm{As}>\mathrm{Zn} \approx \mathrm{Cr} \approx \mathrm{Pb} \approx \mathrm{Cu}$. Among six metals, $\mathrm{Cd}$ was the most heavily polluted, and As was moderately polluted. The concentrations of $\mathrm{Cd}$ and As were 3.92 and 2.77 times higher than the corresponding value of class II of Chinese Soil Environmental Quality Standards ( $\mathrm{pH}>7.5$ ). $\mathrm{Cr}, \mathrm{Cu}, \mathrm{Pb}$, and $\mathrm{Zn}$ contents were lower than the standard value, among which $\mathrm{Cr}, \mathrm{Pb}$, and $\mathrm{Zn}$ were slightly higher than the soil background value of Ningxia. The spatial distribution of $\mathrm{Cd}$ and As was similar, with the hot-spot enrichment in the north and southwest of the study area; and its source was closely related to the industrial production activities in the region. $\mathrm{Zn}$ was mainly accumulated in the southern part of the study area; the $\mathrm{Zn}$ was derived from agricultural practices, such as the wide application of chemical fertilizers and pesticides. In contrast, $\mathrm{Cr}$ and $\mathrm{Cu}$ originated mainly from the natural parent soil material. Different human activities and land use had a significant impact on the enrichment and distribution of trace elements in the soil. For all trace elements except $\mathrm{Zn}$, the content in the industrial land was generally higher, while the content of trace elements in forestland was lower. It should be noted that the contents of As and $\mathrm{Cd}$ in the water body were exceptionally high, indicating a risk of migration and accumulation to rivers and the groundwater. Therefore, effective remediation techniques, such as phytoremediation, should be properly employed for the sustainable development of the soil and groundwater, while reducing the risk of elements to the local residents.

Supplementary Materials: The following are available online at http://www.mdpi.com/2071-1050/12/5/1868/s1. Figure S1: Trace-element concentrations in topsoil samples of Huinong District. Table S1: Best-fitted semivariogram models and the parameters of soil trace elements in Huinong District.

Author Contributions: Conceptualization, X.N. and C.L; data curation, S.Z. and M.A.; formal analysis, S.Z., Y.L., and W.C.; funding acquisition, C.L.; investigation, S.Z., Y.L., Y.Y., and X.N.; methodology, Y.L., Y.Y., and X.N.; project administration, C.L.; resources, X.N and C.L; software, S.Z. and Y.L.; supervision, C.L.; validation, S.Z., Y.L., Y.Y., and W.C.; visualization, S.Z.; writing—original draft, S.Z. and M.A.; writing—review and editing, S.Z., M.A., and C.L.. All authors have read and agreed to the published version of the manuscript.

Funding: This research was funded by the Chongqing Municipality Key Forestry Research Project (No. TD2019-2), Chongqing Municipality Housing and Urban Construction Committee (No. Chengkezi 2019-1-4-2), State Cultivation Base of Eco-agriculture for Southwest Mountainous Land (No. 5330200076), Forestry Extension Project 
of China Central Finance (No. Yulinketui 2017-12), and International Sci-Tech Cooperation Project of Ministry of Science and Technology (No. 2015DFA90900).

Acknowledgments: The authors would like to thank the staff from State Key Laboratory of Seedling Bioengineering for their invaluable help with the field investigation and sampling.

Conflicts of Interest: The authors declare no conflict of interest.

\section{References}

1. Hu, H.; Jin, Q.; Kavan, P. A Study of Heavy Metal Pollution in China: Current Status, Pollution-Control Policies and Countermeasures. Sustainability 2014, 6, 5820-5838. [CrossRef]

2. Li, Z.; Ma, Z.; van der Kuijp, T.J.; Yuan, Z.; Huang, L. A review of soil heavy metal pollution from mines in China: Pollution and health risk assessment. Sci. Total Environ. 2014, 468-469, 843-853. [CrossRef] [PubMed]

3. Nriagu, J.O. Global Metal Pollution: Poisoning the Biosphere? Environ. Sci. Policy Sustain. Dev. 1990, 32, 7-33. [CrossRef]

4. Fernandez-Luqueno, F.; López-Valdez, F.; Gamero-Melo, P.; Luna-Suárez, S.; Aguilera-González, E.N.; Martínez, A.I.; García-Guillermo, M.; Hernández-Martínez, G.; Herrera-Mendoza, R.; Álvarez-Garza, M.A. Heavy metal pollution in drinking water-a global risk for human health: A review. Afr. J. Environ. Sci. Technol. 2013, 7, 567-584.

5. Cui, Y.; Zhu, Y.-G.; Zhai, R.; Huang, Y.; Qiu, Y.; Liang, J. Exposure to metal mixtures and human health impacts in a contaminated area in Nanning, China. Environ. Int. 2005, 31, 784-790. [CrossRef]

6. Mamat, Z.; Yimit, H.; Ji, R.Z.A.; Eziz, M. Source identification and hazardous risk delineation of heavy metal contamination in Yanqi basin, northwest China. Sci. Total Environ. 2014, 493, 1098-1111. [CrossRef]

7. Qing, X.; Yutong, Z.; Shenggao, L. Assessment of heavy metal pollution and human health risk in urban soils of steel industrial city (Anshan), Liaoning, Northeast China. Ecotoxicol. Environ. Saf. 2015, 120, 377-385. [CrossRef]

8. Liu, Y.; Xiao, T.; Baveye, P.C.; Zhu, J.; Ning, Z.; Li, H. Potential health risk in areas with high naturally-occurring cadmium background in southwestern China. Ecotoxicol. Environ. Saf. 2015, 112, 122-131. [CrossRef]

9. Keshav Krishna, A.; Rama Mohan, K. Distribution, correlation, ecological and health risk assessment of heavy metal contamination in surface soils around an industrial area, Hyderabad, India. Environ. Earth Sci. 2016, 75, 411. [CrossRef]

10. Dong, R.; Jia, Z.; Li, S. Risk assessment and sources identification of soil heavy metals in a typical county of Chongqing Municipality, Southwest China. Process Saf. Environ. Prot. 2018, 113, 275-281. [CrossRef]

11. Wilcke, W.; Müller, S.; Kanchanakool, N.; Zech, W. Urban soil contamination in Bangkok: Heavy metal and aluminium partitioning in topsoils. Geoderma 1998, 86, 211-228. [CrossRef]

12. Vink, R.; Behrendt, H.; Salomons, W. Development of the heavy metal pollution trends in several European rivers: An analysis of point and diffuse sources. Water Sci. Technol. 1999, 39, 215. [CrossRef]

13. Wang, G.; Zhang, S.; Xiao, L.; Zhong, Q.; Li, L.; Xu, G.; Deng, O.; Pu, Y. Heavy metals in soils from a typical industrial area in Sichuan, China: Spatial distribution, source identification, and ecological risk assessment. Environ. Sci. Pollut. Res. 2017, 24, 16618-16630. [CrossRef] [PubMed]

14. Rodríguez, J.A.; Nanos, N.; Grau, J.M.; Gil, L.; López-Arias, M. Multiscale analysis of heavy metal contents in Spanish agricultural topsoils. Chemosphere 2008, 70, 1085-1096. [CrossRef] [PubMed]

15. Xia, X.; Chen, X.; Liu, R.; Liu, H. Heavy metals in urban soils with various types of land use in Beijing, China. J. Hazard. Mater. 2011, 186, 2043-2050. [CrossRef] [PubMed]

16. Li, X.; Poon, C.-S.; Liu, P.S. Heavy metal contamination of urban soils and street dusts in Hong Kong. Appl. Geochem. 2001, 16, 1361-1368. [CrossRef]

17. Acosta, J.A.; Faz, A.; Martínez-Martínez, S.; Zornoza, R.; Carmona, D.M.; Kabas, S. Multivariate statistical and GIS-based approach to evaluate heavy metals behavior in mine sites for future reclamation. J. Geochem. Explor. 2011, 109, 8-17. [CrossRef]

18. Yang, Y.; Christakos, G.; Guo, M.; Xiao, L.; Huang, W. Space-time quantitative source apportionment of soil heavy metal concentration increments. Environ. Pollut. 2017, 223, 560-566. [CrossRef]

19. Lado, L.R.; Hengl, T.; Reuter, H.I. Heavy metals in European soils: A geostatistical analysis of the FOREGS Geochemical database. Geoderma 2008, 148, 189-199. [CrossRef] 
20. Hou, D.; O'Connor, D.; Nathanail, P.; Tian, L.; Ma, Y. Integrated GIS and multivariate statistical analysis for regional scale assessment of heavy metal soil contamination: A critical review. Environ. Pollut. 2017, 231, 1188-1200. [CrossRef]

21. Sun, C.; Liu, J.; Wang, Y.; Sun, L.; Yu, H. Multivariate and geostatistical analyses of the spatial distribution and sources of heavy metals in agricultural soil in Dehui, Northeast China. Chemosphere 2013, 92, 517-523. [CrossRef] [PubMed]

22. Huang, Y.; Li, T.; Wu, C.; He, Z.; Japenga, J.; Deng, M.; Yang, X. An integrated approach to assess heavy metal source apportionment in peri-urban agricultural soils. J. Hazard. Mater. 2015, 299, 540-549. [CrossRef]

23. Zhou, J.; Zhou, J.; Feng, R. Status of China's heavy metal contamination in soil and its remediation strategy. Bull. Chin. Acad. Sci. 2014, 29, 315-320.

24. Fan, X.G.; Mi, W.B.; Ma, Z.N.; Wang, T.Y. Spatial and temporal characteristics of heavy metal concentration of surface soil in Hebin industrial park in Shizuishan northwest China. Environ. Sci. 2013, 34, 1887-1894.

25. Yang, Q.; Li, Z.; Lu, X.; Duan, Q.; Huang, L.; Bi, J. A review of soil heavy metal pollution from industrial and agricultural regions in China: Pollution and risk assessment. Sci. Total Environ. 2018, 642, 690-700. [CrossRef] [PubMed]

26. Wang, M.; Peng, C.; Chen, W. Impacts of industrial zone in arid area in Ningxia province on the accumulation of heavy metals in agricultural soils. Environ. Sci. 2016, 37, 3532-3539.

27. Liu, Y.; Yang, Y.; Li, C.; Ni, X.; Ma, W.; Wei, H. Assessing Soil Metal Levels in an Industrial Environment of Northwestern China and the Phytoremediation Potential of Its Native Plants. Sustainability 2018, 10, 2686. [CrossRef]

28. Zhou, Y.; Wei, A.; Li, J.; Yan, L.; Li, J. Groundwater Quality Evaluation and Health Risk Assessment in the Yinchuan Region, Northwest China. Expo. Health 2016, 8, 443-456. [CrossRef]

29. Gergel, S.E.; Turner, M.G.; Miller, J.R.; Melack, J.M.; Stanley, E.H. Landscape indicators of human impacts to riverine systems. Aquat. Sci. 2002, 64, 118-128. [CrossRef]

30. State Environmental Protection Administration of China. Technical Specification for Soil Environmental Monitoring (HJ/T 166-2004); China Environmental Science Press: Beijing, China, 2004.

31. Zhang, X.; Gao, B.; Xia, H. Effect of cadmium on growth, photosynthesis, mineral nutrition and metal accumulation of bana grass and vetiver grass. Ecotoxicol. Environ. Saf. 2014, 106, 102-108. [CrossRef]

32. State Environmental Protection Administration; State Bureau of Technology Supervision. Chinese Environmental Quality Standard for Soils (GB15618-1995); China Environmental Science Press: Beijing, China, 1995.

33. Hakanson, L. An ecological risk index for aquatic pollution control a sedimentological approach. Water Res. 1980, 14, 975-1001. [CrossRef]

34. Chen, T.; Liu, X.; Zhu, M.; Zhao, K.; Wu, J.; Xu, J.; Huang, P. Identification of trace element sources and associated risk assessment in vegetable soils of the urban-rural transitional area of Hangzhou, China. Environ. Pollut. 2008, 151, 67-78. [CrossRef] [PubMed]

35. Goovaerts, P. Geostatistics for Natural Resources Evaluation; Oxford University Press: New York, NY, USA, 1997; pp. 85-97.

36. Ćujić, M.; Dragović, S.; Đorđević, M.; Dragović, R.; Gajić, B. Environmental assessment of heavy metals around the largest coal fired power plant in Serbia. CATENA 2016, 139, 44-52. [CrossRef]

37. Sabin, L.D.; Lim, J.H.; Stolzenbach, K.D.; Schiff, K.C. Atmospheric dry deposition of trace metals in the coastal region of Los Angeles, California, USA. Environ. Toxicol. Chem. 2006, 25, 2334-2341. [CrossRef]

38. Zhao, L.; Xu, Y.; Hou, H.; Shangguan, Y.; Li, F. Source identification and health risk assessment of metals in urban soils around the Tanggu chemical industrial district, Tianjin, China. Sci. Total Environ. 2014, 468-469, 654-662. [CrossRef]

39. Rodríguez Martín, J.A.; Arias, M.L.; Grau Corbí, J.M. Heavy metals contents in agricultural topsoils in the Ebro basin (Spain). Application of the multivariate geoestatistical methods to study spatial variations. Environ. Pollut. 2006, 144, 1001-1012. [CrossRef]

40. Nicholson, F.A.; Smith, S.R.; Alloway, B.J.; Carlton-Smith, C.; Chambers, B.J. An inventory of heavy metals inputs to agricultural soils in England and Wales. Sci. Total Environ. 2003, 311, 205-219. [CrossRef]

41. McBride, M.B.; Spiers, G. Trace element content of selected fertilizers and dairy manures as determined by ICP-MS. Commun. Soil Sci. Plant Anal. 2001, 32, 139-156. [CrossRef] 
42. Maas, S.; Scheifler, R.; Benslama, M.; Crini, N.; Lucot, E.; Brahmia, Z.; Benyacoub, S.; Giraudoux, P. Spatial distribution of heavy metal concentrations in urban, suburban and agricultural soils in a Mediterranean city of Algeria. Environ. Pollut. 2010, 158, 2294-2301. [CrossRef]

43. Liu, X.; Wu, J.; Xu, J. Characterizing the risk assessment of heavy metals and sampling uncertainty analysis in paddy field by geostatistics and GIS. Environ. Pollut. 2006, 141, 257-264. [CrossRef]

44. Thevenon, F.; Graham, N.D.; Chiaradia, M.; Arpagaus, P.; Wildi, W.; Poté, J. Local to regional scale industrial heavy metal pollution recorded in sediments of large freshwater lakes in central Europe (lakes Geneva and Lucerne) over the last centuries. Sci. Total Environ. 2011, 412-413, 239-247. [CrossRef] [PubMed]

45. Krishna, A.K.; Satyanarayanan, M.; Govil, P.K. Assessment of heavy metal pollution in water using multivariate statistical techniques in an industrial area: A case study from Patancheru, Medak District, Andhra Pradesh, India. J. Hazard. Mater. 2009, 167, 366-373. [CrossRef] [PubMed]

(C) 2020 by the authors. Licensee MDPI, Basel, Switzerland. This article is an open access article distributed under the terms and conditions of the Creative Commons Attribution (CC BY) license (http://creativecommons.org/licenses/by/4.0/). 